\title{
Strategies of Integrated Rural Development Adopted by Communities in Delta State
}

O. Ugboh (PhD) and E.U. Tibi (PhD)

\begin{abstract}
The study examined the integrated rural development strategies adopted by communities in rural development in Delta State. The concept of rural development was put forward and the basic idea was that it is a development process embracing the efforts of individuals, self help groups, non-governmental and governmental organisations, collective thinking, collective action and participation. Each of these groups identifying with different roles towards increasing the social and economic well-being of the people and the advancement towards the nation's growth. The study, therefore, identified some integrated rural development strategies and their application to community and rural development processes. These were represented in a schema as stated in figs 1 and 2. The application of these strategies gave rise to the execution of developmental projects like the market stalls, town halls etc. It could be observed that the integrated rural development process takes place through definite structures and strategies used by local agencies to execute developmental projects in which case the several institutions in the community have hands in any given community project.
\end{abstract}

\section{Introduction}

Rural development means a process of social action in which people of the rural area organise themselves for the identification of their needs, planning and action to meet those needs with maximum reliance on their own initiative 
and resources supplemented with assistance in any form from government and non governmental organisations (Bello, 1980). In a broad sense most growing economics have rural development designed to improve life at the local community level as much as our human and material resources can carry us and to develop all aspects of community living equitably, so as to avoid imbalance in, or neglect of any area of living as well as achieve self-generating breakthrough in productivity and to raise the production potentials by stimulating the human and physical processes of change (Esenjor, 1992). Rural development as seen by India's planning commission is the method of rural extension, the agency through which the five year plan seeks to initiate the process of transforming the socio and economic life of the village (Paanikkar, 1974). The Federal government of Nigeria sees rural development as a programme of aided self-help to be planned and implemented by the villagers themselves while the government only offers technical guidance. Its objectives are to develop self-reliance in the individual and initiative in the village community thinking. Collective actions are encouraged through people's institutions like the co-operative societies and development associations, as the DFRRI decree of 1986 stipulates (Koinyan, 1986).

Rural development could be seen as a development process embracing the efforts of individuals, self-help groups, non-governmental and governmental organizations, collective thinking, collective action and participation. Each of these groups identifying with different roles towards increasing the social and economic well being of the people and the advancement towards the nation's growth and to make the efforts of these groups effective and acceptable, the people's identified felt-needs must be priority projects (Dube, 1986). 
Obibuaku (1983) observed that in some countries, notably India, the approach in solving the problem of agricultural underdevelopment is through the process of rural development, which is a movement designed to promote better living for the whole community with the active participation of and, on the initiative of the community.

Rural development operates through enlistment and organization of self-help and co-operative effort on the part of the community, but usually with technical assistance from government and voluntary agencies.

Akin (1978) sees rural development as the collective activities with basic economic and social needs. This implies that a community determines its own future and must do this collectively if it is to realize that vision of its future. No outside body however benevolent and generous, can do this for the community. It is not a matter of money or of sharing a national cake. It is a matter of leadership of fostering the right attitude, promoting a strong work ethics and inculcating the social virtue of hard work, diligence and perseverance in changing the circumstances of one's life for the better. To him rural development is all about teaching a man to fish rather than giving him fish.

Jose (1986) sees rural development as a process of social action in which people of the rural community organise themselves for planning and action, define their individual and common goals to meet their needs, solve their problems and supplement these resources when necessary with services from government and non-governmental agencies outside the community. Community development as a process of social action in which the people of the community organize themselves for planning action, defines their common and individual plan with maximum reliance upon 
community resources and supplement these resources when necessary with services and materials from governmental and non-governmental agencies outside the community (Jose, 1986). The emphasis here is on social action undertaken by the community themselves. Baker (1975) corroborated Jose (1986) when he wrote that in Gradan village, the villagers believed in discussing their problems in the village council where ideas and materials were shared and suggestions for making the village self-reliant were made. He discovered that community development projects were carried out in the following pattern.

(i) Action to be taken

(ii) Suggestions from people

(iii) Contributions to start the project and

(iv) Plans of action for the whole village.

In conclusion, he noted that successful execution of the village project through this means had enabled them survive hard years.

Igbozurike (1977) defines rural development as a regional resources mobilization system in which the conceptual initiatives and responsibility rest with the occupants of the region concerned. The term is also seen as an educational process and activities in rural communities, which embody the principle of self-help. In developed countries, e.g. United Kingdom, a professional expert is employed by the local educational authority to assist and promote the activity. This idea is echoed by Bail (1974) who saw community development as the method by which people in villages are involved in helping to improve their own economic and social working conditions and thereby become effective working groups in programmes of their national development. In order words, it emanates from a mutual agreement among a group of people to mobilise their co- 
operative efforts to embark on programmes that would improve their socio-economic life. Bail (1974) is of the view that rural development is an educational process, which seeks to create improved opportunities for local people to satisfy the human, economic, social and psychic needs. This view was supported by Brainwell and Baker (1975) when they said that rural development is an educational process. It is not better road, better bridge, portable water or effective sanitation, it is something of the spirit more than on the material. It must reach deep into the cultural pattern of the people. It is not a temporary physical constitution. It is building within the mind of man, not a re- creation centre in the middle of the field. The emphasis here is on the internalisation of the culture. Ugboh (2004) sees rural development as a process of people learning how to help themselves attain an improved standard of living by building better communities, taking one step at a time. In progressive step, they acquire knowledge and control of the process of self directed-self help. The importance of participation and efforts on the part of those whose lives are to be affected by the programme is basic to any definition of rural development. The process is therefore, a complex made up of two essential elements. (i) encouraging people to analyse their local problems with a view to improving their levels of living with as much reliance as possible on their own initiatives.

(ii) provision of technical and other services in ways which encourage initiative, self-effort and co-operation.

This point of view emphasises that the people should not only participate in the efforts but also be encouraged to develop their initiative as much as possible. The effectiveness of a rural development programme will depend therefore to a large extent on whether or not government encourages local 
planning and participation in the light of the technical possibilities brought to their attention. If an atmosphere is created in which the citizens feel it is a duty and privilege to contribute their own quota actively to the development of their community, much more is likely to be accomplished than is otherwise possible. Rural development helps the people of a rural community organise themselves for planning and action, define their common and individual needs and execute these plans with maximum reliance upon community resources and supplement these resources when necessary with services and materials from government and nongovernmental agencies. It requires the utilization, under one single programme of approaches and techniques which rely upon local communities as units of action and which attempts to combine outside assistance with organised local selfdetermination and efforts, which correspondingly seek to stimulate local initiatives and leadership as the primary instrument of change. In the economically underdeveloped areas, major emphassis is on the activities which aim at promoting the improvement of basic living conditions of the community, including the satisfaction of some of its non material needs. This description seems to give a true picture of rural development. Nevertheless it is very silent on what should be the primary objective or goal of rural development as to whether it is co-operative work or development of selfdetermination.

Every rural community development programme or project must have its roots in the community, ensuring active involvement and participation of the people from the execution stage. It is and must be a bottom-up development process.

Anyichi (1995) sees rural development as the process of rural modernisation and the monetisation of the rural 158 
society leading to its transition from traditional isolation to integration with the national economy. It is that which aims at the upliftment of the quality of human life comprising social, economic, political and cultural aspects. (Ezeh, 1999). It is a process of growth and progressive change in physical, economic, health, welfare, institutional set ups of a rural community. It involves, adopting one or more approaches in bringing about development in economic, health care and social welfare of members of a community (Osuem 1999). The aims of rural development should be to increase the selfsufficiency of the rural dwellers and raise their standards of living. It enables the people, through group action, become competent to control their living conditions. It is a process of not only increasing the level of per-capita income in the rural sector, but also the standard of living of the rural population (Fakoya, Apantaku and Oyesola 2001)

\section{Statement of Problem}

Esenjor (1992) stated that apart from the trial and error basis, there are several administrative and structural bottlenecks that have stifled most efforts and strategies of integrated rural development in Nigeria. Rural development had not been centrally guided and instead of institutionalising a rural development ministry, the federal government has distributed the development programmes to many ministries. Bostahi (1980), opined that the people do not participate in community development because of lack of potentiality to participate. The erroneous attitude by some practitioners that villagers are illiterate, ignorant, indifferent etc. may certainly influence their style of handing them as it is believed that ones reactions to people is very much dependent upon what assumptions one makes about them and what expectations one has about their behavior. 
Elaigwu (1980), Observed that the village is considered to be a unit of rural development and much will be achieved if it continues to be the unit. But after the village, the town is the bigger unit of development which has been found with the idea of administrative efficiency which has not been recognized as an effective unit except the local government itself. The local government on its own cannot cope effectively with the poor staff in carrying out rural development activities to the grass roots as recognitions are not accorded to the towns and village levels as effective units to meet the target of development.

There are many problems that militate against integrated rural development such as problems of coordination, lack of trained or professional workers, flexibility of rural development agencies, lack of funds, lack of people's participation which tend to impede rural development.

Mordi (1988) asserted that inconsistencies of agencies and other organisations in charge of rural development have complicated the administration of rural development in Nigeria. Several ministries are accorded and assigned with responsibilities duplicated amongst other agencies which have become so fluid that the name and responsibility assigned may not be the same in the next few months and this demonstrates the trial and error syndrome in the Nigeria rural development administration.

Ekong (1977) is of the view that inadequate finance allocation for rural development to the government agencies has been so pathetic and frustrating. Agencies have been in pains over the meagre allocation given for the yearly rural development programmes as not much have been achieved especially as agencies are not given enough to meet up the 
planned progamme and employ professionals and highly qualified personnel due to lack of finance to complete these projects. Yearly claimed allocation for development programmes to these agencies are mainly paper budgetary allocations. Ijere (1990) states that the Nigeria rural development strategy had lacked until recently a philosophical, ideological or holistic foundation. It had a body made up of policy makers and functionaries but no soul to give it life and sense of direction. The usual practice had been to sit on housetops propounding slogans and manifestoes for the people below. Because rural development lacks that philosophical foundation, there is a conspicuous absence of total community participation. Agents of rural development in Nigeria are largely government functionaries who do their best to whip up enthusiasm among the people. This top down approach evokes unwilling response from the people and the paternalism sees the rural people as helpless beings incapable of standing on their fect. Oyaide (1981) states that rural development in Nigeria is segmented or uncoordinated where it is assumed that new programmes in one community will have ripple effects in other institutions or communities. Up till 1976, there was no national rural development programme in Nigeria. Rural questions were dealt with under agriculture and social services and often in isolated and experimental fashion.

Diejemaoh (1973) stated that there is often a tendency among people to regard the social and cultural aspects of development as subordinate to the economic. This attitude has led to many failures in rural development innovations that do not guarantee the cohesiveness of the group and respect their history and beliefs have little hope for survival.

There is the tendency in Nigeria to treat rural development projects as charity or welfare rolls. Few people 
are interested in the costing, evaluating and ensuring that targets are met. It is rare to find a project that pays its way. All must go to the government at the end of the year cap in hand for more money. The potential credit unions, cooperative and other local funding sources including personal savings and local austerity measures are therefore not made use of. Integrated rural development programmes require that there should be certain local leaders who are prepared to motivate and sustain the enthusiasm of the people in the face of conflicts, depressions and unfulfilled expectations but the tendency has been to rely on official leadership for carrying out rural projects. The leadership has not come from within to sustain the momentum and things fall apart whenever the officials have been redeployed (Diejemaoh, 1973).

Ijere (1987) stated that there is the neglect of community structural approach. A structural approach uses existing organisations as much as possible in dealing with problems and people. It calls on the resources of existing institutions and works through them. Where these are not available, it builds structure models such as leadership committees for the projects or communities involved but the usual pattern in Nigeria has been to impose as much imported schemes as possible whether they are related to the cultural and sociological life of the people or not. They appoint new local leaders where such leaders already exist not making use of youth organisations, age grade and women groups in the initiation and implementation of programmes.

Olatunbosun (1975) stated that rural development demands the co-operation of all arms of public and private sectors. The task is often left for the government alone. It funds, motivates people, implements and evaluates. As its limited funds are over stretched, it throws in the towel and so 
we see a large number of uncompleted roads, market stalls, hospitals etc all over the place. No serious attempt is made to enlist the support and co-operation of public, private and voluntary sectors such as banks, breweries and other ministries. Olayide (1982) is of the view that women are the greatest force in rural development all over the world. In everyday life, they are found in the homes, farms, markets, offices, and praying houses. They out number the men in all these places and are visibly present and aggressive in what they believe in.

In Nigeria, it is the men who sit in councils to decide the policy and do the budgeting for the rural areas even when they reside in the urban communities. It is the men that implement and quarrel over the sharing of the cake. They interpose legal, social and economic obstacles to prevent women from competing with the men, and what little training opportunity that are on ground is usually grabbed by the men without consideration for the special needs of women and their high potential in rural development.

\section{Purpose of Study}

To highlight the integrated rural development strategies adopted by communities in ensuring rural development in Delta State.

\section{Strategies of Integrated Rural Development Adopted by Communities in Rural Development in Delta State.}

Rural development has been conceived as a method or process of tackling the problems of community organisation in order to bring about economic development. The framework of community development consists of the process of community development which focus upon the sequences 
through which communities or their segments and their leaders, go as they move from a pre-industrial to an industrial type. It is also a similar kind of overall change, the methods to be used in moving toward their objectives as they focus upon accomplishments rather than upon sequences, a programme that has been carefully thought through in procedures. It is a movement as it is more than a mere programme. Olayide (1988) is of the view that the main weapon for tackling the problems of rural development from the colonial times was community development. The areas most emphasized were social welfare, adult education, and stimulation of self-help and self-reliance.

In a broad sense, most growing economies have rural development designed to improve life at the local community level as much as our human and material resources can carry us and to develop all aspects of community living equitably so as to avoid imbalance or neglect of any area of living as well as achieve self-generating breakthrough in productivity and to raise the production potentials by stimulating the human and physical processes of change (Esenjor.1992)

Infact, the central goal of community development is to develop in a rapid manner, the enormous growth potentials of the rural community resources as a means of stimulating a more rapid development of the overall economy. In order to reach the goals of community development, measures have been taken to minimize poverty and unemployment in the villages, explore and use technical assistance available from outside the community, co-operate with and co-ordinate state and national development plans (Esenjor 1992). For the attainment of the stated measures, a wide range of strategies/policies have been initiated and implemented and these have been classified in many ways such as authoritarian 
handouts, development from below and integrated rural development.

The authoritarian handout stipulates the prescription of facilities suitable for the rural areas just as the practice in the colonial era, and this has continued till today under many guises. A type of paternalism which dictated the number of clinics, post offices, kilometers of roads, schools and market stalls that could be allotted to the rural areas after the urban centres has been surfeited with many and could not accommodate any more.

The so called development from below implies mounting development agencies in the rural areas making use of local leaders in decision-making over their own affairs with limited assistance from government. This is shown in the concept of community village councils, autonomous communities and county or local government councils that became the political arrangements for implementing this strategy for rural development.

The integrated approach involves development in which urban and rural areas are considered as an integral part of the planning object. In other words better health, education, infrastructure and better living standards, which had been the preserve of urban areas form part and parcel of the strategy in the development process of rural areas as well.

Diejemaoh (1973) added that other strategies of rural development include the growth point or growth pole centre model which emphasises the development of a few strategic towns and industries that are likely to activate other sectors. The key settlement as it assumes a focal point for a given rural area and the concentration of all rural 
development resources in such a settlement, which in turn is able to serve other regions through its network of roads and communication.

The decentralised territorial approach frowns against towns and all forms of urban connubations considering them exploitative and parasitic but prefers a dispersal of benefits in rural areas. This model has minimum linkage with the city but with settlements of various sizes to act as service and market centres. It has been observed that through these approaches or models, rural development could be attained, but it is being stressed in development literature that for rural development programmes, to ensure the active involvement and contribution of the total rural community who should be educated, to share responsibility along with the benefits of development. To ignore the optimum utilization of the development process is to lose the battle even before it starts (Brown, 1979).

The elimination of rural poverty and the improvement of the living standards of the rural people require their participation in those organised efforts, as the achievement of rural development tasks alone by external intervention will not bring about development of the community as people do not get the feeling that they are participants in the endeavour and so, there is need to try to get people to respond to development programme initiated by others for their benefit. Thus apart from community and local group contribution in rural development programmes, individual participation and contribution is also important to demonstrate to the people the habit of belonging and self-reliance (Lele, 1975).

Lately, awareness emerged among government planners, bureacrats and rural development specialists of the need to involve the local people and their leaders in the 
formulation and implementation of change programmes, as this new initiative stands against the top-down or authoritarian handout model (Esenjor, 1992). But the people centred model, which is diametrically opposed to the topdown model sees the local people and their leaders as creative force whose initiatives, talents and resources can be mobilised for effective rural development.

This model also recognises that the local leaders and their people are much more familiar with their local environment than experts and the model further sees the creative potentials, knowledge and energies of the rural people as indispensable ingredients for self-reliant development.

The broader and more comprehensive conception of participation is one in which the local leaders and their people are intimately involved in the identification of needs into scale of priorities in the selection and siting of projects, in the mobilisation of necessary resources for and in the identification of needs and problems and in the sharing of the benefits and burdens deriving from these projects(Dahama and Bhanagar, 1985).

This is similar to the idea of social action. It is necessary to involve people or their representatives effectively in the process of development and while achieving the tasks of involvement we should not bring about disparity among people on gender lines or interms of possession or profits. Care should be taken to ensure the effective participation of all sections of the community in order to maintain social equilibrium and the required high morale. Participation and involvement should not be restricted to the already more prosperous sections of the population, but the rural poor who are more likely to be neglected should be consulted and involved (Okafor, 1984). Olatunbosun (1975) 
opined that citizens participation is deeply inherent in the very concept of community development which enjoins that whatever is done to improve the welfare of people must endeavour to elicit the enthusiasm and whole hearted participation of the people. Citizen participation stipulates that the people for whom any project is being designed must be allowed to take part in the planning, execution, utilisation and assessment of the social amenities or facilities. It is such participation that gives the people the pride of ownership of the facilities completed in the process of rural development as could be derived with the social action process.

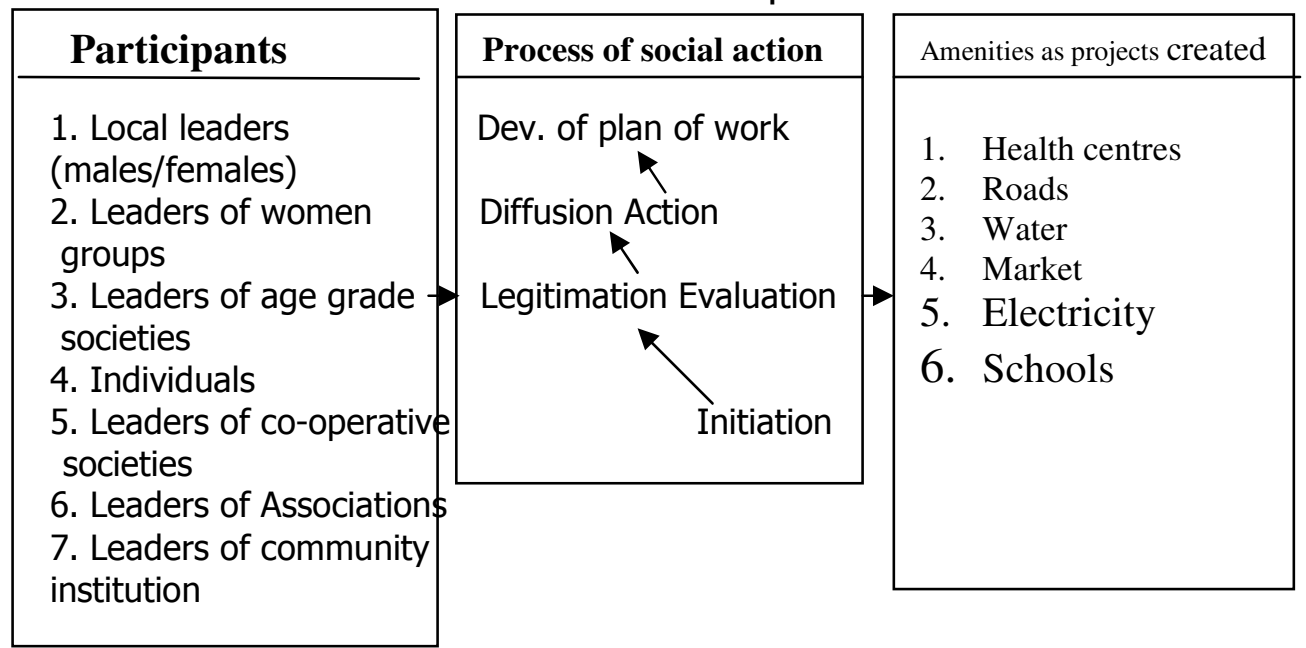

Fig. 1.0: A representation of the rural development process through the social action process.

Apart from citizens participation in rural development through the social action process and other models outlined above, rural development can be attained through self-help, self-reliance and self-initiative of developmental projects. Selfreliance is seen as the major and most important aim and 
objective of community work. The concept of self-help promotes self-reliance to a great extent. Self-reliance is impossible unless members of the community co-operate and work together as a team (Self-help). Self-reliance refers to a situation where the community provides for most of their basic needs with little or no external assistance. This is no doubt possible through community work, to ensure the improvement of life at the local community level as fast as the human and material resources can carry them.

Self-help approach discloses the need to encourage communities of people to identify their own needs and to work co-operatively at satisfying them. As needs are defined and solutions sought, aid may be provided by national government or international organisations. The emphasis here is on communities of people working at their own problems, change as they see the need for change and develop the will and capacity to make changes feel desirable. The people should be so involved that the economic burden of the programmes become the responsibility of the local people. If these programmes have to be successfully implemented and people made conscious about their utility value, they have to become economically self-dependent and the whole programme should be based on collective thinking, collective action and collective participation in various programmes. Self-help projects are usually less capital intensive, made up of projects tailored to suit the community's resources, such as the construction and repair of feeder and earth roads, the clearing of bush paths and village squares, the building of small community halls and the construction of public wells. These projects are usually initiated by the people themselves, and involves a high degree of community participation in raising the financial and material input required for the projects. With the increasing educated sons and daughters of 
various rural communities, resident in towns, the dominance exercised by local community development officials over the initiation, design and implementation of such projects is gradually ending.

\section{Participants}

1. Local leaders

2. Leaders of women groups

3. Individuals

4. Leaders of rural organizations

5 . Leaders of rural institutions

6 . Leaders of development agendie

7. Leaders of age grade

markets

Development
Dev. Model

1. Bottom up approa

2. Self-help approach

3. Self-reliance

4. Growth point model

5. Authoritarian handout

6. Social action process

7. Integrated rural

8. Communications

9. Security/vigilante

10. Esusu groups/banks
Project Executed

1. Community halls

2. Rural roads

3. Health care

4. Water scheme

5. Schools

6. Electricity

7.Community

Fig. 2.0: A schematic representation of the strategies adopted in integrated rural development.

\section{Conclusion}

Rural development is a process that is not merely continuous but takes place principally through definite structures and strategies used by the local agencies to execute developmental projects such that the various institutions in the community have hands in any given community project even if one is formally charged with the initiation and co-ordination of development projects as it does not exclude exchange of information and resources, bargaining between and among interest groups outside and within the community.

The link between the boxes in fig. 1.0 and 2.0 are based on the fact that community development process follow a sequential pattern of action which are embedded in most community development models or strategies and this 
involves such models as the bottom up model, self-help approach, self reliance, growth point model, authoritarian handout, integrated rural development and the social action process which involves a functional category of activities like the initiation stage, legitimation, diffusion, development of the plan of work, action stage and evaluation. The outputs from these models are usually expressed in the form of community projects that are executed by the participants. This is the stage where you translate action into concrete achievements through various projects like those identified as the community halls, rural roads, health care schemes, water schemes, markets, communications, security, banks etc. as shown in the schema.

\section{References}

Akin, N. (1978) Perspectives on Community and Rural Development in Nigeria Center for Development studies (CDS) UNIJOS.

Anyichi, D (1995) "Models of Rural Development in Nigeria; with special focus on ADPS" in Eboh, E.C., Okoye C.U, and Anyichi D. (Ed) Rural Development in Nigeria. Concepts, Processes and prospects. Enugu: Auto century publishing Co

Bail, G.A (1974) "Nature of Rural Development proceeding" Priorities in Rural Development. University of Guelph, Canada.

Bello, H.O. (1980), Federal-State Relation in National planning, Proceeding of the 1980 symposium, organised and published by Nigerian Economic society.

Baker, J. (1975) Peoples Participation in Development Administration in India Uppal Publishing house New Delhi 
Boostahi I. (1980), Rural Development and Developing Countries. Oslow Canada, the Alger Press Ltd.

Brown, P.L. (1979) Administrative Development in India. Sterling Publishers Ltd. New Delhi.

Dahama, O.P. and Bhatnagar, O.P. (1985) Education and Communication for Development, New Delhi, India: Oxford and I.B.H. Publishing Co.

Diejemaoh, V.P. (1973) Rural Development in Nigeria: The Role of Fiscal Policy in Rural Development in Nigeria. Ibadan.

Dube, D.C. (1986) India Dwelling Villages: Human Factors in Community Development. Roultedge and Kegan Paul, London.

Ekong, E.E. (1977) "The Administration of Community Development in Nigeria" A Critical Appraisal and suggested alternative. The Quarterly Journal of Administration. Vol. XI No.3 Pp.154-155.

Elaigwu, J.I. (1980) Local Government and Political Development. The Challenges of Participation and control in Grassroot Government in Nigeria. In Aliyu A.Y. (Eds) African Development Policies. Enugu: Acena Publishers.

Esenjor, A.F. (1992) "People's participation in Community Development" A Lecture presented during the 1989, Rural day celebration at SSRD, Kano.

Ezeh, P.N. (1999) "Agricultural Education as an Impetus of Rural growth and Development in Nigeria". Nigeria Journal of Agricultural Education. Vol.2 Nos. 1 X 2 Pp. 97-100.

Fakoya, G.O. Apantaku, S.O. and Onyesola, O.B. (2001) "Contributions of Local Associations in Community 
Development Projects in Ondo State Nigeria" Journal of Agriculture and Social Research Vol.1 No.2 Pp. 50-61.

Ijere, M.O. (1987) Rural Development in Imo-State: The Problem of Implementation at the Grassroots. A paper presented at the N.T.A. Workshop in Aba.

Jose, D.M. (1986), People's Participation and integrated Rural Development Programme, Kurukshetra. AugustSeptember.

Koinyan, L. (1988) DFRRI, the way out. National Concord Press (Nig) Ltd, Lagos. 15 $5^{\text {th }}$ July, 1988.

Lele, U. (1975), The Design of Rural Development Lessons from Africa: John Hopkin University Press.

Mordi, A.A. (1988) "Theoretical Approaches to Community Development. An over view" A Seminar paper published by centre for Development Studies. University of Jos.

Obibuaku, L.O. (1978) Agricultural Extension as a strategy for Agricultural Transformation. Nsukka: University of Nigeria, Press.

Okafor, F.C. (1984) "Dimensions of Community Development projects in Bendel State, Nigeria". Public Admin and Development. Vol.4, Pp.249-258.

Olatunbosun, D. (1975) Nigeria Neglected Rural Majority, Ibadan: Oxford University Press.

Olayide, S.O. (1982) "Nigeria Small Farmers" Ibadan: U.I. Press.

Osuem, C.E. (1989) "Adult Education and Community Development" in Samuel Chukwuka Enyibe, Curriculum Fundamentals of Adult Education. Essays in Comparative Education. Onitsha: Innouson Pub. Ltd.

Oyaide, O.F. (1981) "Progress Report by the Chairman and Federal Director of Rural Development. Third meeting 
of National Committee on Rural Development" Enugu Pp.11-12

Oyaide, O.F. (1988) "Rural Development in Nigeria - the Role of Government" February Lecture - CRDC, UNN, February 29.

Panikkar, K.K. (1974) Community Development Administration in Kerela. New Delhi S. Chana and Co. PVT. Ltd.

Ugboh, O. (2004) "Role of Local Leaders in Rural and Community Development in Delta State". Unpublished: Ph.D Thesis, Dept of Ag.ext, Futo. 